ISSN: 2663-9181

www.readersinsight.net/jpvai

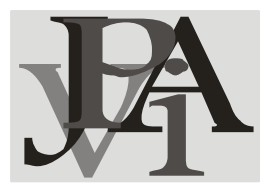

\title{
Chronological studies of lean and leadership for improvement of organizational performance
}

\author{
Maryam Usmani ${ }^{* 1}$, Abdul Sami $^{2}$, Sajjad Ahmad Baig ${ }^{3}$, Asmara Irfan $^{4}$ \\ ${ }^{1}$ Faculty of Management Science, National Textile University, Faisalabad \\ ${ }^{2}$ Department of Administrativet Sciences, University of the Punjab, Jhelum Campus, Jhelum \\ ${ }^{3}$ Faculty of Management Science, National Textile University, Faisalabad \\ ${ }^{4}$ Azman Hashim International Business School, Universiti Teknologi Malaysia, Malysia \\ * Corresponding author: maryamusmanibwp@gmail.com
}

\begin{abstract}
The objective of this review is to identify the most effective characteristics of leaders to enable lean implementation, and helps the organization to improve or change their already implemented strategies to enhance performance through lean. The litreture aim to measure the leadership style for implementation of lean contributes towards building behaviors of leaders that supports the change process like lean. The methodology contains peer reviewed journal, which uncovered 67 reviewed articles from 2003-2017. The conclusion after review explore that senior management and human resources must support and operationalized such opportunity of development. The development is purposed to enable lean implementation. The proper implementation of leadership behaviors improved the success of lean system and validates to achieve high sustainability in performance.
\end{abstract}

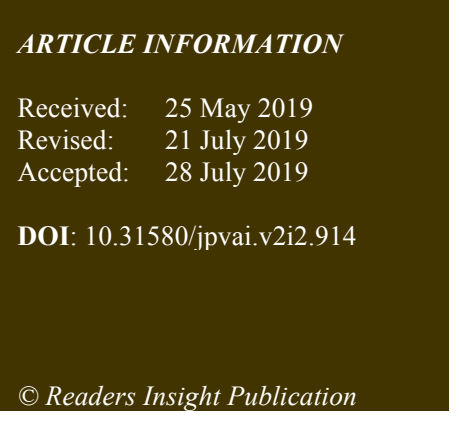

\section{INTRODUCTION}

The effective implementation of lean system in developed organizations leads to enhance its implementation globally. Additionally, the competition between organizations is increasing with the passage of time, according to (Almani et al., 2012), an improved and efficient techniques and tools are required to achieve a competitive edge. However, it can be accomplished with practical lean management. Therefore (Nogueira et al., 2018; Van Landeghem, 2014) explains the growing concern of organization towards lean implementation while describing multiple unproductive and ineffective cases of lean operation. The factors for lean success identified by (Saad et al., 2006) for the effective implementation. Nowadays, the critical aspect within organizations is the support towards change. This change includes work environment, economic condition and crisis (Pamfilie et al., 2012) considered leaders role in support to these changings. Limited research focused on the role of leadership in development of lean. The characteristics of leadership is studied by (Gelei et al., 2015) and the effect of some other factors like leaders age, experienced is discussed by (Tortorella et al., 2018).

The review is proposed to research the broad impact of leadership on lean with is not discussed by (Gelei et al., 2015; Tortorella et al., 2018) It will identify that leadership is more significant factor for the successful implementation of lean. This literature will suggest the most effective characteristics of leaders to enable lean implementation, and helps the organization to improve or change their already implemented strategies for further enhancement of Lean.

\section{LITRETURE REVIEW}

\section{Lean}

Lean is the reduction of non-value added activities from the overall process with the enhancement of production and quality. (Vijaya Sunder, 2015)Now a day, lean is considered as the leading competitive edge by eliminating waste involve in practices and limiting waste from the process. An efficient system needed a considerable set of standards and principles which can handle change and objectives for the improvement of persistent process. It was initially introduced by Toyota (1950) (Ohno, 1988), as Toyota Production System (TPS). The major objectives of TPS were to eliminate muda (waste) for achieving enhanced efficiency. Japanese introduced the term muda which means waste. (Dahlgaard \& Mi Dahlgaard-Park, 2006) defined that the significance of muda concept is increasing within practices related to improving quality. TPS set the philosophy for management whose main purpose is the reduction of waste by the elimination of non-value added activities (Alsmadi et al., 2012).

Leanness is a way of thinking proposed to essentially decrease cost and process duration all through the whole chain of value, while proceeding to improve performance of production (Taylor, Wan, \& Chen, 2012). Controlling cost through lean is the major improvement in process, the operating force behind corporate overall revenue and income development. Strategic techniques for the achievement of productive objectives, businesses must progressively depend on cutting cost, eliminating waste, improved productivity and enhanced quality. Moreover, there is a developing requirement for the representatives to take an interest in and lead the significant changes in current culture of business, working framework and practices. These practices include cutting cost, waste elimination and enhanced production and quality(Street, Fliedner, \& Mathieson, 2010)Their exist all type of waste for lean but the basic seven wastes are extra production, waiting, conveyance, extra processing, inventory, excess motion and defects (Endsley, Magill, \& Godfrey, 2006). 
Additionally (Bhuiyan \& Baghel, 2005) proposed that tools and techniques, people involvement and constant improvement are the basic concepts of lean. The most significant tool of lean includes Value stream mapping (VSM), which used for the visual analysis of process flow. It ensures the stability in each step of process for the continuous flow of stream. It identifies waste from the process flow and eliminates non value added activities from flow. (Rother \& Shook, 2003) study included value stream mapping and other techniques of lean that is just-in-time, kaizen, pull system, $5 \mathrm{~s}$, six sigma etc. (Shah \& Ward, 2007) took keen analysis for the identification of other lean components which incorporates involvement of customers and employees, feedback from suppliers and customers, reduction in cycle time, total productive maintenance TPM and total preventive maintenance.

The study of (Taylor, Storch, Storch, \& Lim, 2010) suggest that the main focus of lean is the elimination of complete waste from the production system. . The background of lean is established on two basic terms: JIT and jidoka. (Gupta \& Jain, 2013) discuss the basic goals of lean, to deliver yield with improved quality at the most diminished possible cost at minimum time by waste elimination. Lean concept empowers waste reduction, restricting instability and cost reduction by adapting multiple stream line mapping technique for process (Vinodh \& Joy, 2012).

\section{Leadership Styles}

Leadership is defined as "the ability of an individual to influence, motivate, and enable others to contribute toward the effectiveness and success of the organizations of which they are members" (House et al., 2001). While number of studies conducted on leadership styles, the major focus of researchers still follow the appropriate classification of leadership. (Northouse, 2010) develops a brief description on behaviors and styles of leadership, which must be followed by every leader for the sustainability and success of organizations. Every leader has its own visions, values, point of views and the way they guide their subordinates and team members. Their way of guiding suggests the individual about perception of success and arrangements leaders should follow to let their team follow success. (Robbins and Judge, 2011) discussed theories based on the ability of leaders to influence their team for the achievement of mutual objectives. It included behavioral theory, contingency theory, leader-member exchange theory, trait theory etc.the argument presented by (Van Eeden et al., 2008) included that the effectiveness of leaders is stable if he/she follows the arranged multiple styles of leadership.

Avolio \& Bass (2004) discussed the significance of basic three leadership: transformational, transactional and laissez faire. The discussion incorporates the similarities differences and their stable implication towards team and organization success. These styles can be classified as transformation leadership who build promises to help employees achieving their objectives, transactional leadership includes logical exchange of promises for rewards and benefits of sub ordinates.

Additional (Papworth et al., 2009) presents a situational leadership model, for the characterization of leadership. This model have effective impact on the changing habits of leaders through collaboration and communication for the productive enhancement (Pasaribu, 2015; Peterson et al., 2011). Though style of leadership appears to be surely known, the stimulating factor is the readiness of individual related to specific style of leadership (Graeff, 1997; Thompson \& Glasø, 2015). The style of leadership may be accepted or rejected depending on the performance outcomes (Avery \& Ryan, 2002)

Yahaya \& Ebrahim (2016); (Sami et al., 2016); (Claxton \& Sarti, 2014) and (Opoku et al., 2015) defined the two basic styles of leadership that is transformational and transactional leadership. Established on the research of (Liu et al., 2003), multiple leadership style: empowering, directive, transactional and transformational. The distinction between theses styles are their characteristics (Pearce et al., 2003)

Transactional leadership, a transaction among top and lower management that is employees and managers. It includes the recognition of accomplishment and promising rewards by leaders, results in enhanced performance (Bass, 1911). It has two dimension, dependent reward and management by exception, active and passive approaches. According to (Den Hartog et al., 1997), contingent reward is considered as the rewards given by the leaders to employees after achieving a certain performance level. In management by expectation, if the actual outcomes are different then desired one only than leader interface with employees.

Transformational leadership, a leader style that support and develop employee's interest, creating awareness about team objectives, assigning rewards to employees for better performance in group instead of individual effort. It is further classified into leader as charismatic, vision achiever, gained trust. A leader who give respect to each employee and fulfill their emotional needs, set responsibility among multiple levels of employees. This style provides a different ways for solving problem (Bass, 1911). (Rafferty \& Griffin, 2004) classified transformational leadership into multiple dimensions as, vision, motivating communication, intellectual encouragement, supportive leadership, personal acknowledgment.

Directive leadership, a leader who infrequently allow sub ordinates to participate in making decisions or giving ideas (Liu et al., 2003). He/ she give directions, knowledge, allocate objectives, opportunities. Employees feel pressure under working such kind of leadership style (Pearce et al., 2003).

Empowering leadership, a leader can be classified into two dimensions: the "power-sharing" "self-efficacy". Power sharing includes the power and accountability emphasize given to subordinates. While self-efficacy excludes the vulnerability and enhancement of motivation (intrinsic) ( $\mathrm{Li}$ et al., 2016). The two dimensions of this leadership style as "the power is shared within employees by essentially allocating multiple levels according to the job significance (Zhang \& Bartol, 2010). It provides high power of making decisions, communicating trust and confidence on the capabilities of employees. (Konczak et al., 2000) discussed six dimensions of this style as power allocation, self-esteem, sharing information, developing skills and training for extra ordinary performance.

\section{Lean and Leadership}

The relationship analyzed by (Gelei et al., 2015), was lean and leadership and divided leadership into three forms: inhibitor, neutral and contributor. The outcomes showed that there is no set of leadership characteristics (behaviors) which interfere or inhibited towards the lean system success. Additionally, research included two behaviors of leadership as contributing in lean success that is communicative (social) and directing as (micro manager). Similarly (Aij et al., 2015) emphasized that leader should perceived the intend of process by practical observation of the processes. The study also highlighted that communication with sub-ordinates, employee promotion and empowerment, trust on employees and openness to experience are the key factors of leadership which positively affect lean success.

Van Assen, (2018) further analyzed the positive relation of leadership empowerment with implementation of lean success, negative relation of servant leadership with lean while no impact of transformational leadership was found. Lately (Tortorella \& Fogliatto, 2017) introduced the ideal leadership style matrix in automation firms. The conclusions indicated that this matrix supports the identification of phases in implementation of lean process. No specific style of leadership identified as more useful for success of lean system, however (Poksinska et al., 2013) mention that multiple behaviors of leadership represented by lean managers can be considered as transformational leadership style. 
Number of studies only focus on the characteristics and behaviors of leadership separately, no link created with lean. Mann (2017) presented the initial studies for the leader role in lean. The study organized the leadership role as a progress and development, and introduced the dimension of lean leadership. Multiple characteristics of leader were identified which enables the leader to direct organization with journey of lean. Sami et al, (2018) identified the different dimensions of public value and establish the relationship of leadership and lean thinking.

Looking back to the origin of lean, the development of leaders for lean devoted by Toyota. The basic values of leaders determined by Toyota as the constant improvement "kaizen", the operation based on knowledge "genchi genbutsu", teamwork promotions, and shared respect promotion. These values can be indicated as constant challenge towards lean approach (Liker \& Convis, 2012). A comparative analysis of western and Toyota manufacturing firms showed that WM depend on mutual trainings of employees and manager, while Toyota devotes on leaders development(Liker \& Convis, 2012).

The ultimate principle of lean leadership derived by (Dombrowski \& Mielke, 2013), through reviews, survey and analysis. The research indicated that leadership is not the direct act of adding value to outcomes but they have the ability to contribute towards the effectiveness and efficiency of performance through directing employees and setting suitable working environment. Alefari, Salonitis, \& Xu (2017) created a clear link among leaderships and lean management. They mention how an employee should engage by leader and let them improved the performance and outcomes of organization. They also termed lean system and leadership into basic principles as: "Gemba", "cultural improvement", education, "selfdevelopment" and developing policies.

According to (Van Dun, Hicks, \& Wilderom, 2017), transformational and transactional styles of leadership are both included in lean leaders. The major focus of transformational leaders is the development and empowerment of employees while transactional leaders follows the idea of lean (eliminate waste) by the utilization of resources in efficient way.

The implementation lean system stimulates a significant variation in management system of organizations (Karlsson \& Åhlström, 1996; Wan \& Frank Chen, 2008). (Bhasin \& Burcher, 2006; Hines et al., 2004) presented literatures to highlights the significance of lean practices and leadership towards organizational progress, development and sustainability. The role of leaders for establishing lean system is essential for organization (Shook, 2010), the key characters of leaders are their responsibilities to influence teams and individuals, to direct employees their duties for the achievement of goals and objectives with less wastage of time and resources. (R. J. House et al., 2004) discussed the opportunities concerning the characteristics and behaviors of leadership are created by the lean implementation. (Mann, 2009) highlights that the major efforts of lean process focused on varying behaviors of leaders while lean practices and tools have minor effect on lean implementations.

The study of (Spear, 2004; Womack \& Jones, 1997) focused on lean leadership, and mentioned the significance of leadership characteristics such as communication and commitment on lean. (Angelis et al., 2011; Pamfilie et al., 2012) underlined certainties that leaders who go through implementation of lean must support, delegate, participate and motivates individuals. Additional, research of (Suresh et al., 2012) suggested that organizations required the transformational style at the top to implement successful process of change like lean system.

Gelei et al. (2015) investigated the contribution of leadership characteristics towards lean success. Emiliani \& Emiliani (2013) searched the queries about the determinants of leadership styles for the transformation of lean implementation to organizational success.

Toyota Motors are the predecessors of Lean implementations, and this corporation is considered as benchmark for lean leadership relationship (Liker \& Convis, 2012). The Toyota way of life was formed by characters, qualities and practices of the organizations authority, which highlights the distinct styles of leadership at Toyota: readiness to experience and availability to achieve objectives and prerequisite.

The personal engagement of leader with the organization lead to create a comfort zone for leader (Trenkner, 2016). van Assen (2018) viewed inconsistency in characteristics and styles of lean leaders, leaders must include specialized technical skills, empower and cooperate with employees to boost performance, innovation and add values to outcomes (Lam et al., 2015).

In term of high dependency of lean implementation on employees of organization, it is important to realize leadership (Bhasin \& Burcher, 2006). In context of lean success, the major management characteristics of leadership highlighted by (Spear, 2004; Womack et al., 1990) are commitment of leaders and their skills. (Suresh et al., 2012) included leadership in Six Sigma.

Parry, Mills, \& Turner (2010) discussed the different contextual variables of leadership which included the age of leader. The study indicated that superior experience of leader's results in enhanced interpersonal skills which in turn favor leaders to select proper leadership style that would support lean success more efficiently.

\section{METHODOLOGY OF THE STUDY}

There were many research articles worked on lean and leadership separately. To achieve high quality Review of Literature about relationship between lean and leadership, various methods were followed.

The initial stage of methodology included peer reviewed journals, which uncovered 67 reviewed articles from 2003-2017. The searched Databases included Google scholar, Research gate, and Emerald insights, Taylor and Francis, Science direct. Secondly, the review also considered sub references from each article for further references. Finally, multiple journals related to review interest were selected independently, included the following publications; The Leadership quarterly, Leadership and Organization Development Journal, Journal of Occupational and organizational psychology, International Journal of Management Science and Engineering Management, Journal of Organizational Change Management, Harvard Business Review, European Management Journal and Academy of Journal Management etc.

\section{CONCLUSION}

The conclusion suggest that to measure the leadership style towards implementation of lean contributes towards building behaviors of leaders that supports the change process like lean. It also helps to sustain the system for long time. The chain of lean and leadership starts with the appropriate style of leader to empower motivate and delegate employees. These motivation and empowerment results in value added work by the employees with the removal of non-value added activities like, employee waiting, takt time, making map of the process flow. Senior management and human resources must support and operationalized such opportunity of development. The purpose of this development is to enable lean implementation. The proper implementation of leadership behaviors improved the success of lean system and validates to achieve high sustainability in performance.

\section{References:}

Aij, K. H., Visse, M., \& Widdershoven, G. A. M. (2015). Lean leadership: an ethnographic study. Leadership in Health Services, 28(2), 119-134.

Alefari, M., Salonitis, K., \& Xu, Y. (2017). The Role of Leadership in Implementing Lean Manufacturing. Procedia CIRP, 63, 756-761. https://doi.org/10.1016/j.procir.2017.03.169

Alsmadi, M., Almani, A., \& Jerisat, R. (2012). A comparative analysis of Lean practices and performance in the UK manufacturing and service sector firms. Total Quality Management \& Business Excellence, 23(3-4), $381-396$.

Angelis, J., Conti, R., Cooper, C., \& Gill, C. (2011). Building a highcommitment lean culture. Journal of Manufacturing Technology 
Management, 22(5), 569-586.

Avery, G. C., \& Ryan, J. (2002). Applying situational leadership in Australia. Journal of Management Development, 21(4), 242-262.

Avolio, B. J., \& Bass, B. M. (2004). Multifactor leadership questionnaire (MLQ). Mind Garden, 29.

Bass, B. M. (1911). Leadership : Learning to Share the Vision, 19-31.

Bhasin, S., \& Burcher, P. (2006). Lean viewed as a philosophy. Journal of Manufacturing Technology Management, 17(1), 56-72.

Bhuiyan, N., \& Baghel, A. (2005). An overview of continuous improvement: from the past to the present. Management Decision, 43(5), 761-771.

Claxton, J., \& Sarti, D. (2014). Leadership styles to engage employees: evidence from human service organizations in Italy. Journal of Workplace Learning.

Dahlgaard, J. J., \& Mi Dahlgaard-Park, S. (2006). Lean production, six sigma quality, TQM and company culture. The TQM Magazine, 18(3), 263281.

Den Hartog, D. N., Van Muijen, J. J., \& Koopman, P. L. (1997). Transactional versus transformational leadership: An analysis of the MLQ. Journal of Occupational and Organizational Psychology, 70(1), 19-34.

Dombrowski, U., \& Mielke, T. (2013). Lean leadership-fundamental principles and their application. Procedia Cirp, 7, 569-574.

Emiliani, M. L., \& Emiliani, M. (2013). Music as a framework to better understand Lean leadership. Leadership \& Organization Development Journal, 34(5), 407-426.

Endsley, S., Magill, M. K., \& Godfrey, M. (2006). Creating a lean practice. Family Practice Management, 13(4), 34.

Gelei, A., Losonci, D., \& Matyusz, Z. (2015). Lean production and leadership attributes-the case of Hungarian production managers. Journal of Manufacturing Technology Management, 26(4), 477-500.

Graeff, C. L. (1997). Evolution of situational leadership theory: A critical review. The Leadership Quarterly, 8(2), 153-170.

Gupta, S., \& Jain, S. K. (2013). A literature review of lean manufacturing International Journal of Management Science and Engineering Management, $8(4)$

$241-249$ https://doi.org/10.1080/17509653.2013.825074

Hines, P., Holweg, M., \& Rich, N. (2004). Learning to evolve: a review of contemporary lean thinking. International Journal of Operations \& Production Management, 24(10), 994-1011.

House, R. J., Hanges, P. J., Javidan, M., Dorfman, P. W., \& Gupta, V. (2004) Culture, leadership, and organizations: The GLOBE study of 62 societies. Sage publications.

House, R., Javidan, M., \& Dorfman, P. (2001). Project GLOBE: an introduction. Applied Psychology, 50(4), 489-505.

Karlsson, C., \& Åhlström, P. (1996). Assessing changes towards lean production. International Journal of Operations \& Production Management, 16(2), 24-41.

Konczak, L. J., Stelly, D. J., \& Trusty, M. L. (2000). Defining and measuring empowering leader behaviors: Development of an upward feedback instrument. Educational and Psychological Measurement, 60(2), 301313.

Lam, M., O’Donnell, M., \& Robertson, D. (2015). Achieving employee commitment for continuous improvement initiatives. International Journal of Operations \& Production Management, 35(2), 201-215.

Li, M., Liu, W., Han, Y., \& Zhang, P. (2016). Linking empowering leadership and change-oriented organizational citizenship behavior: The role of thriving at work and autonomy orientation. Journal of Organizational Change Management, 29(5), 732-750.

Liker, J. K., \& Convis, G. L. (2012). The Toyota way to lean leadership. McGraw-Hill,

Liu, W., Lepak, D. P., Takeuchi, R., \& Sims, H. P. (2003). Matching leadership styles with employment modes: strategic human resource management perspective, 13, 127-152. https://doi.org/10.1016/S10534822(02)00102-X

Mann, D. (n.d.). The Missing Link : Lean Leadership, 15-26.

Mann, D. (2017). Creating a lean culture: tools to sustain lean conversions. Productivity Press

Nogueira, D. M. da C., Sousa, P. S. A., \& Moreira, M. R. A. (2018). The relationship between leadership style and the success of Lean management implementation. Leadership \& Organization Development Journal, 39(6), 807-824.

Ohno, T. (1988). Toyota production system: beyond large-scale production. crc Press.

Opoku, A., Ahmed, V., \& Cruickshank, H. (2015). Leadership style of sustainability professionals in the UK construction industry. Built Environment Project and Asset Management, 5(2), 184-201.

Pamfilie, R., Petcu, A. J., \& Draghici, M. (2012). The importance of leadership in driving a strategic Lean Six Sigma management. Procedia-Social and Behavioral Sciences, 58, 187-196.
Papworth, M., Milne, D., \& Boak, G. (2009). An exploratory content analysis of situational leadership. Journal of Management Development (Vol. 28). https://doi.org/10.1108/02621710910972706

Parry, G., Mills, J., \& Turner, C. (2010). Lean competence: integration of theories in operations management practice. Supply Chain Management: An International Journal, 15(3), 216-226.

Pasaribu, F. (2015). The situational leadership behavior, organizational culture and human resources management strategy in increasing productivity of private training institutions. Information Management and Business Review, 7(3), 65.

Pearce, C. L., Cox, J. F., Ball, G., Schnell, E., \& Smith, K. A. (2003). beyond A multi-method development of a theoretical typology of leadership (Vol. 22). https://doi.org/10.1108/02621710310467587

Peterson, M. F., Ashkanasy, N. M., \& Wilderom, C. P. M. (2011). The Handbook of Organizational Culture and Climate. Sage Publications, Inc.

Poksinska, B., Swartling, D., \& Drotz, E. (2013). The daily work of Lean leaders-lessons from manufacturing and healthcare. Total Quality Management \& Business Excellence, 24(7-8), 886-898.

Rafferty, A. E., \& Griffin, M. A. (2004). Dimensions of transformational leadership: Conceptual and empirical extensions. The Leadership Quarterly, 15(3), 329-354.

Rother, M., \& Shook, J. (2003). Learning to see: value stream mapping to add value and eliminate muda. Lean Enterprise Institute.

Saad, S., Perera, T., Achanga, P., Shehab, E., Roy, R., \& Nelder, G. (2006). Critical success factors for lean implementation within SMEs. Journal of Manufacturing Technology Management.

Sami, A., Jusoh, A., \& Qureshi, M. I. (2016). Does Ethical Leadership Create Public Value? Empirical Evidences from Banking Sector of Pakistan. International Review of Management and Marketing, 6(4S).

Sami, A., Jusoh, A., Md. Nor,K., Irfan,I., \& Qureshi, M. I. (2018). Systematic Review of Public Value. Journal of Public Value and Administration Insights, 1(1), 1-6.

Shah, R., \& Ward, P. T. (2007). Defining and developing measures of lean production. Journal of Operations Management, 25(4), 785-805.

Shook, J. (2010). How to change a culture: Lessons from NUMMI. MIT Sloan Management Review, 51(2), 63-68.

Spear, S. J. (2004). Learning to lead at Toyota. Harvard Business Review, 82(5), 78-91.

Street, M., Fliedner, G., \& Mathieson, K. (2010). Learning Lean : A Survey of Industry Lean Needs, (October 2014), 37-41. https://doi.org/10.3200/JOEB.84.4.194-199

Suresh, S., Antony, J., Kumar, M., \& Douglas, A. (2012). Six Sigma and leadership: some observations and agenda for future research. The TQM Journal, 24(3), 231-247.

Taylor, P., Storch, R. L., Storch, R. L. E. E., \& Lim, S. (2010). Production Planning \& Control: The in shipbuilding I mproving ${ }^{-}$ow to achieve lean manufacturing in shipbuilding. Engineering, (April 2012), 37-41.

Taylor, P., Wan, H., \& Chen, F. F. (n.d.). International Journal of Production A leanness measure of manufacturing systems for quantifying impacts of lean initiatives, (November 2012), 37-41. https://doi.org/10.1080/00207540802230058

Thompson, G., \& Glasø, L. (2015). Situational leadership theory: a test from three perspectives. Leadership \& Organization Development Journal, 36(5), 527-544.

Tortorella, G., \& Fogliatto, F. (2017b). Implementation of lean manufacturing and situational leadership styles: An empirical study. Leadership and Organization Development Journal, 38(7), 946-968. https://doi.org/10.1108/LODJ-07-2016-0165

Tortorella, G. L., de Castro Fettermann, D., Frank, A., \& Marodin, G. (2018). Lean manufacturing implementation: leadership styles and contextual variables. International Journal of Operations \& Production Management, 38(5), 1205-1227.

Trenkner, M. (2016). Implementation of lean leadership. Management, 20(2), $129-142$.

van Assen, M. F. (2018). Exploring the impact of higher management's leadership styles on lean management. Total Quality Management \& Business Excellence, 29(11-12), 1312-1341.

Van Dun, D. H., Hicks, J. N., \& Wilderom, C. P. M. (2017). Values and behaviors of effective lean managers: Mixed-methods exploratory research. European Management Journal, 35(2), 174-186.

Van Eeden, R., Cilliers, F., \& Van Deventer, V. (2008). Leadership styles and associated personality traits: Support for the conceptualisation of transactional and transformational leadership. South African Journal of Psychology, 38(2), 253-267.

Van Landeghem, H. (2014). A management system for sustainable lean implementation. In Handbook of research on design and management of lean production systems (pp. 173-187). IGI Global. 
Vijaya Sunder, M. (2015). Corporate perspectives: commonalities and differences between Six Sigma and Lean. Sigma, 6(3), 281-288.

Vinodh, S., \& Joy, D. (2012). Structural Equation Modelling of lean manufacturing practices. International Journal of Production Research, 50(6), 1598-1607. https://doi.org/10.1080/00207543.2011.560203

Wan, H., \& Frank Chen, F. (2008). A leanness measure of manufacturing systems for quantifying impacts of lean initiatives. International Journal of Production Research, 46(23), 6567-6584.

Womack, J. P., \& Jones, D. T. (1997). Lean thinking — banish waste and create wealth in your corporation. Journal of the Operational Research Society, 48(11), 1148

Womack James, P., Jones, D. T., \& Roos, D. (1990). The machine that changed the world. New York: Rawson.

Yahaya, R., \& Ebrahim, F. (2016). Leadership styles and organizational commitment: literature review. Journal of Management Development, $35(2), 190-216$

Zhang, X., \& Bartol, K. M. (2010). Linking empowering leadership and employee creativity: The influence of psychological empowerment, intrinsic motivation, and creative process engagement. Academy of Management Journal, 53(1), 107-128 